\title{
Strategic planning and performance measurement using balanced scorecard: A case study of Iran Kaolin and Barite company
}

\author{
A. Danaei and A. Omidifard*
}

Department of Management, Semnan Branch, Islamic Azad University, Semnan, Iran

\begin{tabular}{l}
\hline C H R O N I C L E \\
\hline Article history: \\
Received January 18, 2013 \\
Received in revised format \\
10 May 2013 \\
Accepted May 152013 \\
Available online \\
May 162013 \\
\hline Keywords: \\
BSC \\
Balanced scorecard \\
Strategic planning \\
\hline
\end{tabular}

\section{A B S T R A C T}

\begin{abstract}
This paper presents an empirical investigation to measure the performance of a mining firm in province of Semnan, Iran based on balanced scorecard (BSC). The proposed study investigates the present status of the case study in terms of four BSC perspectives including internal process, learning and growth, customer and financial figures. The firm uses BSC for one year and after that, we compared the performance of the firm prior and after BSC implementation. The preliminary results indicate that the firm was able to make a $30 \%$ improvement on its performance after one-year implementation of BSC. In other words, the firm was able to make $59 \%$ improvement on learning and growth, 33\% growth on internal process, $32 \%$ growth on customer and $21 \%$ improvement on financial figures.
\end{abstract}

\section{Introduction}

The success of any business unit depends entirely on the quality of its management and management quality depends on decision quality and information quality on the quality of its measurement and proportion. Therefore, its accuracy and measurement has essential role on the success of the business unit and the weakness of performance evaluation and managerial control system can create some barriers for the growth of organization. There are literally numbers of methods and techniques to measure the relative performance of a firm. Balanced score card (BSC) is one of the most popular techniques for measuring the performance of business units in terms of four different perspectives including internal process, learning and growth, customer and financial figures. Kaplan and Norton are believed to be the first who introduced the idea of BSC (Kaplan \& Norton, 1996, 2000, 2002, 2004). Mozaffari et al. (2012) performed a BSC method to measure the performance of a university based organization based on an adaptation of fuzzy numbers for handling the existing uncertainty on the numbers.

${ }^{*}$ Corresponding author. Tel: +989121316312

E-mail addresses: a.omidifard1353@gmail.com (A. Omidifard)

(C) 2013 Growing Science Ltd. All rights reserved. 
Danaei and Hosseini (2013) investigated the existing strategic objectives in the strategy map of a pipe company located in city of Shiraz, Iran and designed a questionnaire and distributed it among 31 managers, 94 regular employees and 110 customers of this firm for the fiscal year ended 2011. The results of their study indicated that the firm could reach $41.4 \%$ of its financial objectives, $87.38 \%$ of its customers' requirements, $66.13 \%$ of internal processes and $70.94 \%$ of its learning necessities according to four major BSC requirements.

Kohneh et al. (2013) implemented a hybrid of analytical hierarchy process along with BSC to measure the performance of five different civil registry offices in Tehran, Iran. They used fuzzy terms to handle uncertainty in input numbers and using some technique convert fuzzy numbers into crisp values. The results of their survey indicated that learning and development was number one priority with relative importance of 0.491 , followed by customer with relative importance of 0.293 , internal process with relative importance of 0.173 and financial affairs comes at last with relative weight of 0.043. The study also implemented organizational researchers, training, quality, customer satisfaction, performance measurement, expenses and annual budget as major components for analyzing five regions.

Nemati et al. (2013) developed a comprehensive method to learn the impact of knowledge management $(\mathrm{KM})$ practices on organizational performance. They used BSC to materialize this comprehensiveness. In order to prevent research dispersion, the selective indicators in KM were oriented to some critical success factors influencing KM implementation. In addition, they analyzed the factors by path analysis using structural equation modeling (SEM). The results indicated that KM practices maintained some impacts on the overall performance. Finally, KM practices only impacted learning and growth among dimensions of BSC, significantly.

Mozaffari et al. (2013) in a comprehensive investigation measured the performance of Islamic Azad University of Semnan by the utilization of strategy map as a prominent part of BSC. Darvish et al. (2012) evaluated the effect of human resource competencies on productivity by considering different issues such as various competencies associated with human resources, how it was possible to persuade and strengthen such competencies in organizations and whether human resource competencies could impact organizational productivity or not. The results of their survey indicated that that human resource competency could impact organizational productivity. In addition, all dimensions of human resource competencies had significant relationship on organizational productivity.

Ghotbuee et al. (2012) presented an empirical investigation to measure the relative efficiency of seven health care centers in province of Semnan, Iran, which were under the coverage of social security organization of Iran. They implemented a hybrid of balanced score card and data envelopment analysis for performance measurement based on BSC method. The preliminary results indicated that all seven units perform relatively well and the overall efficiency of all units in this province is 0.769 .

\section{The proposed study}

This study investigates the effects of the implementation of BSC on measuring the relative performance of and Iranian firm called Iran Kaolin and Barite company located in province of Semnan, Iran. Iran Kaolin and Barite company was established in 1992 and it produces and provides mineral products needed by industries such as oil and gas drilling, chemical and ceramic. The company is one of major producers of industrial mineral powders such as Barite, Bentonite and Hematite according to API, OCMA \& ASTM standards, micronized calcium carbonate, Kaolin, Talc, Feldespar, Silicaflour and other mineral powders. The firm is also active in exporting its products to the countries in the Persian Gulf region and CIS countries. 
In order to measure the performance of this firm, we consider the present status of the firm, setup some targets and measure the performance of the firms one year after in terms of four BSC perspectives.

\section{The results}

We first present details of different attributes used for measuring BSC performance in our implementation. Table 1 summarizes all necessary attributes.

\section{Table 1}

The summary of BSC figures prior to implementation

\begin{tabular}{|c|c|c|c|c|c|c|c|c|}
\hline Perspective & Value added process & Attribute & Unit & Identity & Present & Ideal & Score & Overall \\
\hline \multirow{2}{*}{$\begin{array}{l}\text { Learning \& } \\
\text { Growth }\end{array}$} & Improving knowledge & Improvement in educations & Person & Positive & 2 & 10 & $89 \%$ & \\
\hline & of employee & Improvement in short courses & Hour & Positive & 24 & 100 & $19 \%$ & 29 \\
\hline \multirow{5}{*}{$\begin{array}{l}\text { Internal } \\
\text { process }\end{array}$} & Treatment process & Visit drainage treatment ponds & Dropout & Negative & 50 & 20 & $20 \%$ & \\
\hline & Production process & Volume of production & Tonnage & Positive & 42000 & 47050 & $25 \%$ & \\
\hline & Maintenance process & Production interruption & Hour & Negative & 52 & 10 & $71 \%$ & 32 \\
\hline & & The value of equipment & Currency & Positive & 200 & 1000 & $42 \%$ & \\
\hline & Quality control process & Lesions & Percent & Negative & 40 & 10 & $40 \%$ & \\
\hline \multirow{4}{*}{ Customer } & Process & Quality of product & Based on 7 & Positive & 5 & 7 & $60 \%$ & \\
\hline & & Sales increase & Percent & Positive & 25 & 60 & $80 \%$ & 53 \\
\hline & Marketing process & Identifying new markets & Case & Positive & 2 & 5 & $80 \%$ & \\
\hline & & Variety of Customers & Case & Positive & 18 & 30 & $89 \%$ & \\
\hline \multirow[b]{2}{*}{ Financial } & & Percentage of debt reduction & Percent & Positive & 8 & 10 & $19 \%$ & \\
\hline & Financial process & $\begin{array}{l}\text { Percentage Increase in } \\
\text { working capital }\end{array}$ & Percent & Positive & 12 & 15 & $20 \%$ & 80 \\
\hline Total & & & & & & & & 48 \\
\hline
\end{tabular}

As we can observe from the results of Table 1, there were some serious issues on all measures of BSC methods and presently the performance of the organization is around $48 \%$. In order to improve the performance of the firm, the management team executed some programs and after one year we repeated our assessment on the firm. Table 2 summarizes the results of our survey as follows,

Table 2

The summary of performance measurement after BSC implementation

\begin{tabular}{|c|c|c|c|c|c|c|c|c|}
\hline Perspective & Value added process & Attribute & Unit & Identity & Present & Ideal & Score & Overall \\
\hline \multirow{2}{*}{$\begin{array}{l}\text { Learning \& } \\
\text { Growth }\end{array}$} & Improving knowledge & Improvement in educations & Person & Positive & 3 & 10 & $30 \%$ & \\
\hline & of employee & Improvement in short courses & Hour & Positive & 40 & 100 & $40 \%$ & 35 \\
\hline \multirow{5}{*}{$\begin{array}{l}\text { Internal } \\
\text { process }\end{array}$} & Treatment process & Visit drainage treatment ponds & Dropout & Negative & 28 & 20 & $71 \%$ & \\
\hline & Production process & Volume of production & Tonnage & Positive & 45200 & 47050 & $96 \%$ & \\
\hline & Maintenance process & Production interruption & Hour & Negative & 30 & 10 & $33 \%$ & 52 \\
\hline & & The value of equipment & Currency & Positive & 300 & 1000 & $30 \%$ & \\
\hline & Quality control process & Lesions & Percent & Negative & 35 & 10 & $29 \%$ & \\
\hline \multirow{4}{*}{ Customer } & Process & Quality of product & Based on 7 & Positive & 5.5 & 7 & $79 \%$ & \\
\hline & & Sales increase & Percent & Positive & 30 & 60 & $50 \%$ & 70 \\
\hline & Marketing process & Identifying new markets & Case & Positive & 4 & 5 & $80 \%$ & \\
\hline & & Variety of Customers & Case & Positive & 22 & 30 & $73 \%$ & \\
\hline \multirow[b]{2}{*}{ Financial } & & Percentage of debt reduction & Percent & Positive & 10 & 10 & $100 \%$ & \\
\hline & Financial process & $\begin{array}{l}\text { Percentage Increase in } \\
\text { working capital }\end{array}$ & Percent & Positive & 41 & 15 & $93 \%$ & 97 \\
\hline Total & & & & & & & & 62 \\
\hline
\end{tabular}

As we can observe from the results of Table 2, there have been significant changes on the performance of the firm in terms of four different BSC perspectives. In other words, learning and growth has increased from 29 to 35, internal process was improved from 32 to 52, customer was upgraded from 53 to 70 and finally, financial figures were improved from 80 to 97 percent. Overall performance of the firms was improved from 48 to 62 percent leaving us to conclude that BSC has been able to make some changes on the business unit. 


\section{Conclusion}

In this paper, we have presented an empirical investigation on measuring the relative performance of an organization based on the implementation of balanced scorecard. We have setup some figures in terms of four BSC perspectives and measured the performance of the firms one year before and after the implementation of the BSC technique. The results have indicated that there had been some improvements on the performance of the firm in terms of four different BSC perspectives. In other words, learning and growth was increased from 29 to 35, internal process was improved from 32 to 52, customer was upgraded from 53 to 70 and finally, financial figures were improved from 80 to 97 percent. Overall performance of the firms was improved from 48 to 62 percent leaving us to conclude that BSC has been able to make some changes on the business unit.

\section{Acknowledgment}

The authors would like to thank the management team of Iran Kaolin and Barite company for cordially participating in this program and cooperated with us to implement this program.

\section{References}

Danaei, A \& Hosseini, A. (2013). Performance measurement using balanced scorecard: A case study of pipe industry. Management Science Letters, 3(5), 1433-1438.

Darvish, H., Moogali, A., Moosavi, M \& panahi, B. (2012). An empirical study on human resource competencies and its relationship with productivity. Management Science Letters, 2(7), 26152624.

Ghotbuee, A., Hemati, M \& Fateminezhad, R. (2012). An empirical study based on BSC-DEA to measure the relative efficiencies of different health care centers in province of Semnan, Iran. Management Science Letters , 2(7), 2643-2650.

Kaplan, R.S., \& Norton, D.P. (1996). Using the balanced scorecard as a strategic management system. Harvard Bus. Review (January.February). 74(1), 75-85.

Kaplan, R.S., \& Norton, D.P. (2000). The strategy-focused organization: How balanced scorecard companies thrive in the new business environment. Harvard Bus. School Press.

Kaplan, R.S., \& Norton, D.P. (2002). Building the Balanced Scorecard in Public Sector. Balanced Scorecard Report from Interview with Rick Pagsibigan, September 19.

Kaplan, R.S., \& Norton, D.P. (2004). Strategy maps: Converting intangible assets into tangible outcomes. Boston, MD: Harvard Bus. School Press.

Kohneh, A., Yazdani, B \& Kamalian, A. (2013). Performance measurement in governmental agencies using BSC-AHP: A case study of Civil Registry Office in Tehran. Management Science Letters, 3(4), 1255-1260.

Mozaffari, A., Karkehabadi, H., Kheyrkhahan, M \& Karami, M. (2012). A development in balanced scorecard by designing a fuzzy and nonlinear Algorithm (case study: Islamic Azad university of Semnan). Management Science Letters, 2(5), 1819-1838.

Mozaffari, A., Kalaei, H., Shahhosseini, M \& Chaghouee, Y. (2013). A new framework for performance evaluation system using strategy map: A case study of Islamic Azad University of Semnan. Management Science Letters , 3(4), 1041-1048.

Nemati, B., Ghaemi, V \& Rashidi, M. (2013). The Effect of KM implementation on organizational performance with balanced scorecard methodology. Management Science Letters, 3(3), 10251036. 